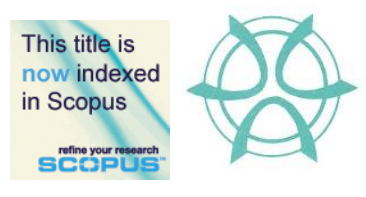

PLANNING MALAYSIA:

Journal of the Malaysian Institute of Planners

VOLUME 16 ISSUE 2 (2018), Page 83 - 88

\title{
DESIGN ELEMENTS OF HOUSES AMONG DISABLED COMMUNITY: THE SATISFACTION AND THE PREFERENCES
}

\author{
Syakir Amir Ab Rahman ${ }^{1}$, Nasriah Samsudin², Mariana Mohamed \\ Osman $^{3}$, Syahriah Bachok $^{4}$, \& Noor Suzilawati Rabe ${ }^{5}$ \\ Kulliyyah of Architecture and Environmental Design \\ INTERNATIONAL ISLAMIC UNIVERSITY MALAYSIA
}

\begin{abstract}
Home ownership creates stability and improves the quality of life of the disabled communities. As Malaysia approaches the developed status and the high income economy by 2020 , the housing industry needs to be adaptive to the demands for special groups. Universal homes incorporate universal design principles, resulting in a living environment that can be adapted to virtually any user's long term comfort, safety and ease. The aim of this paper is to study on the preferences and level of satisfaction on design factor in owning residential property among the disabled community in Kuala Lumpur and Selangor. A questionnaire survey was conducted on a sample of 800 respondents. The respondents were selected from the disabled community, focusing on two categories of disabilities, physical and visual impairment. The outcome of this study shows that disabled people prefer houses which are complete with design that accommodates residents' physical limitations. For design elements of their residential property, this study found that the disabled people are satisfied with the provision of ramp to access into the building, while their satisfaction on design for the low physical effort scored at seventh place. The study concludes with two housing recommendations: to provide at least the minimum requirement of universal design in all upcoming projects and to provide home modification scheme.
\end{abstract}

Keyword: disabled community, residential property, universal design, home ownership, preferences 
Syakir Amir Ab Rahman, Nasriah Samsudin, Mariana Mohamed Osman, Syahriah Bachok, \& Noor Suzilawati Rabe

Design Elements of Houses Among Disabled Community: The Satisfaction and The Preferences

\section{INTRODUCTION}

Home ownership or the ability to own residential property has been a goal for every Malaysian including the disabled communities. According to Coates, Anand and Norris (2015), owning a residential property provides sense of security which leads to happiness, productive and fulfilling of one's life.

As Malaysia approaches developed nation status and becomes a highincome economy by 2020 , the housing industry needs to be adaptive to the demands of the special groups. Government needs to provide and plan suitable housing policies for all. Everyone shares the right to a decent standard of living. The fulfillment of human life beyond simple survival is access to adequate housing. The Adaptable or Lifetime Home is a concept developed during the 1980s in several European countries including Norway, The Netherlands and Great Britain. It is a normal dwelling intended for all kinds of households, but constructed with foresight so that it can be inexpensively transformed to fit the changing requirements of its residents throughout their lives or those of a disabled member, if so required (Nolte, 1988).

\section{Design of House for the Disabled People}

Different impairment will need different types of facilities (Osman, Radzi, Bakri, \& Ibrahim, 2015). Universal homes incorporate universal design principles, resulting in a living environment that can, with little difficulty and expense, be adapted to virtually any user's long term comfort, safety and ease. Among the characteristics of barrier free adaptable housing to make it become more preferable for disabled people are:

i. It allows free access to buildings, housing units and services for people with mobility, hearing or vision limitations.

ii. It provides adequate turning and working space for wheelchairs in housing units and public spaces.

iii. It improves the safety of people engaged in normal daily activities.

iv. It provides features that increase safety in emergencies.

v. It provides features that make it easier to use and maintain the building, dwelling units and equipment.

\section{People with Disability}

People with disabilities (PWDs) in Malaysia can be considered as one of the most vulnerable of the minority group in the Malaysian population. World Health Organization (WHO) and World Bank estimated that there were 15\% of the world population has some form of disabilities. According to the Department of Social Welfare Malaysia, this percentage did not refer to all disabled people in Malaysia because the data were incomplete. This is due to the fact that the registration of PWDs in Malaysia was not compulsory, and was done based on a voluntary basis. 
PLANNING MALAYSIA

Journal of the Malaysia Institute of Planners (2018)

Persons with Disabilities Act (Act 685) defines a person with disabilities (PWDs) as those who have long - term physical, mental, intellectual or sensory impairments which in interaction with various barriers may hinder their full and effective participation in society. Referring to the Person with Disabilities Act (Act 685) there are seven categories of disabled people which are visually impaired, hearing impaired, lack of physical effort, learning issue, speech disabilities, mental disabilities and less effort wide.

\section{Disabled Community in Malaysia}

According to Jabatan Kebajikan Malaysia or known as JKM (2016a), there are 356,677 people with disabilities registered in Malaysia as of 2015. However, as the registration was voluntary, the data was not completely reflective of the actual numbers in the country.

Table 1: Registration of person with disabilities (PWDs), 2013 -2015

\begin{tabular}{cc}
\hline Year & Number of cases \\
\hline 2013 & 264,448 \\
2014 & 318,132 \\
2015 & 365,677 \\
\hline
\end{tabular}

Source: JKM (2016a)

Based on Table 1 the numbers of registered PWDs were increasing from year 2013 to 2015. There were 365677 registered PWDs in 2015. The total of PWDs in Malaysia covered 1.2\% of the total population in Malaysia.

Table 2: Registration of person with disabilities (PWDs) by State, 2015

\begin{tabular}{ll}
\hline States & Number of cases \\
\hline Johor & 45,953 \\
Kedah & 32,983 \\
Kelantan & 25,947 \\
Melaka & 18,391 \\
Negeri Sembilan & 17,273 \\
Pahang & 21,946 \\
Perak & 33,020 \\
Perlis & 4,404 \\
Pulau Pinang & 22,094 \\
Sabah & 22,806 \\
Sarawak & 25,037 \\
Selangor & 55,594 \\
Terengganu & 18,281 \\
W.P Kuala Lumpur & 20,911 \\
W.P. Labuan & 1,037 \\
\hline Total & $\mathbf{3 6 5 , 6 7 7}$ \\
\hline Source: JKM(2016b) &
\end{tabular}


Syakir Amir Ab Rahman, Nasriah Samsudin, Mariana Mohamed Osman, Syahriah Bachok, \& Noor Suzilawati Rabe Design Elements of Houses Among Disabled Community: The Satisfaction and The Preferences

Table 2 shows the number of registered PWDs in Malaysia by states. As shown in the table, Selangor had the highest registered number of PWDs with 55, 594 while Kuala Lumpur had 20, 911 registered PWDs.

\section{METHODOLOGY}

For the sampling method, this research was conducted by using purposive sampling. The sampling focused on two categories of disabilities which were physical and visual impairment. The reason behind the sampling selection was that approximately $90 \%$ of the worlds' visually impaired live in low-income settings (World Health Organization, n.d.). It was also because $28 \%$ of 25 to 64 year-olds with severe physical disabilities fall far below the federal poverty line - nearly four times the rate for people of the same age who were not disabled (Karaim, 2002).

Questionnaire survey was distributed to the sample size of 800 respondents from shelter homes and organization of physical and visual impairment people in Kuala Lumpur and Selangor. The researchers also went to the the related PWDs assembly and dialogue's programme, including the paralympic tournaments.

\section{FINDING AND ANALYSIS}

\section{Mean Score of Preferred and Current Satisfaction on Design of House}

Based on Table 3, the design of a house that encourage low physical effort scored the $1^{\text {st }}$ ranked characteristic with mean score of 8.94. Provision of elevator scored the $2^{\text {nd }}$ highest ranked characteristic with mean score of 8.91. The design of disabled friendly washroom scored the $3^{\text {rd }}$ highest ranked characteristic with mean score of 8.78 while ramp to access the building scored $4^{\text {th }}$ highest ranked characteristic with mean score of 8.58. The handrail scored a mean of 8.55 and level one bathroom or bathroom located near to main room scored a mean of 8.51. The disabled friendly kitchen design scored a mean of 8.46. Finally, the least preferred characteristic was a house with disabled friendly bedroom, with mean score of 8.44 .

Table 3: Score of characteristic for preferred design of house

\begin{tabular}{lcc}
\hline Statement & Mean & Rank \\
Design of house encourage the low physical effort & 8.94 & 1 \\
Elevator is provided for disabled person & 8.91 & 2 \\
Design of washroom is disabled friendly & 8.78 & 3 \\
Complete with ramp to access into building & 8.58 & 4 \\
Handrail is provided & 8.55 & 5 \\
$\begin{array}{l}\text { Bathroom is provided at level one or near to main room for } \\
\text { disabled }\end{array}$ & 8.51 & 6 \\
\hline
\end{tabular}


PLANNING MALAYSIA

Journal of the Malaysia Institute of Planners (2018)

Design of the kitchen is disabled friendly

$8.46 \quad 7$

Have a bedroom designed for disabled person

$8.44 \quad 8$

As shown in Table 4, houses complete with ramps to access into building was ranked the highest with mean score of 5.92. The lowest mean score was the disabled friendly kitchen design with 5.02 mean score. Compared to the most preferred design element, housing design that encourage low physical effort was ranked $7^{\text {th }}$ place with a median of 5.10. The result showed that the current needs of the PWDs were not fulfilled which can affect the percentage of housing ownership among the PWDs.

Table 4: Score of current satisfaction for design of house

\begin{tabular}{lcc}
\hline Statement & Mean & Rank \\
Complete with ramp to access into building & 5.92 & 1 \\
Elevator is provided for disabled person & 5.65 & 2 \\
Bathroom is provided at level one or near to main room for & 5.62 & 3 \\
disabled & 5.55 & 4 \\
Design of washroom is disabled friendly & 5.33 & 5 \\
Have a bedroom designed for disabled person & 5.10 & 6 \\
Handrail is provided & 5.10 & 7 \\
Design of house encourage the low physical effort & 5.02 & 8 \\
Design of the kitchen is disabled friendly & & \\
\hline
\end{tabular}

\section{RECOMMENDATIONS}

This study found that the current satisfaction on housing design does not meet the preferences of the PWDs. Hence, two recommendations are suggested in response to the PWDs housing issues:

\section{i. Provide at least the minimum elements of universal design in all housing unit.}

Universal design elements are not only designated for the PWDs, but also for the aging population. Therefore, there is a need for each housing unit in the upcoming housing projects to implement at least the minimum requirement or elements of universal design. The government is urged to make this requirement as compulsory to all housing developers and efficiently implemented in the enforcement. The house should at least (i) have unobstructed width of doors with minimum width of $850 \mathrm{~mm}, 900 \mathrm{~mm}$ or more, (ii) provide ramp to access into the house and (iii) have toilet that are complete with disabled facilities such as level one toilet, suitable toilet seat, foldable grab rail, independent water supply beside toilet seat and wash hand basin at suitable height for wheelchair users. 
Syakir Amir Ab Rahman, Nasriah Samsudin, Mariana Mohamed Osman, Syahriah Bachok, \& Noor Suzilawati Rabe Design Elements of Houses Among Disabled Community: The Satisfaction and The Preferences

\section{ii. Home modification scheme}

Every day disabled individuals find that their homes need to be modified in a way that gives them easier access. These modifications make it possible for them to stay in their home and live an independent life. Home adjustments come in all shapes and sizes and can vary in cost from one manufacturer and contractor to another.

The ideas of this proposal are designated for the PWDs that already own a house but still require housing modification to cater their needs. Among the types of housing modifications that can be offered are:

a. Change of bathroom and toilets that disabled friendly

b. Modification of kitchen to be user-friendly for disabled people

c. Installation of ramp, grab rails and handrails

d. Expanding of the doorways

e. Other modification needed by the disabled people

\section{CONCLUSION}

In conclusion, the main characteristic to be considered in planning the house for PWDs was the barrier-free design. Based on the findings, the PWDs need affordable houses that encourage the low physical effort.

The preferred characteristics of housing design for the PWDs have been highlighted in this study. It is essential for related government or housing agencies to learn from the success and failures of other countries in improving the housing needs of PWDs' through related housing policies for the PWDs.

\section{REFERENCES}

Coates, D., Anand, P., \& Norris, M. (2015). Housing, happiness and capabilities: A summary of the international evidence and models. Open Discussion Papers in Economics 81, The Open University. Retrieved from https://www.econstor.eu/handle/10419/147532

Jabatan Kebajikan Masyarakat [JKM] (2016a). Report on statistic of registered disabled community in Malaysia.

Jabatan Kebajikan Masyarakat [JKM] (2016b). Categories of disabled community in Malaysia.

Osman, M. M., Radzi, F. H. M., Bakri, N. I. M., \& Ibrahim, M. (2015). Barrier-free campus: Universiti Malaya, Kuala Lumpur. Procedia - Social and Behavioral Sciences, 168, 134-144.

Nolte, E. A. H. (1988). Building adaptable housing Nationale Woningraad. Almere, The Netherlands

Karaim, R. (2002). People with physical disabilities.

World Health Organisation [WHO] (n.d.). World report on disability. Retrieved from http://www.who.int/disabilities/world_report/2011/en/ 